\title{
HOW TO CREATE A NATIONAL OPERA? THE LISINSKI CASE IMAGINARY MEMOIRIST SKETCHES WITH AN EPILOGUE
}

\author{
VJERA KATALINIĆ \\ Hrvatska akademija znanosti i umjetnosti
}

Izvleček: Članek obravnava razmere $v$ štiridesetih letih 19. stoletja, ko so rodoljubi zaprosili mladega skladatelja Vatroslava Lisinskega (1819-1854), da napiše nacionalno opero. Ni bil dovolj glasbeno izobražen za tako nalogo, pa tudi pesniki niso bili dovolj izkušeni s pisanjem libretov. V obliki izmišljenega skladateljevega monologa so predstavljeni njegovi dvomi in ravnanje, zasedba in izvedba njegove opere Ljubav in zloba.

Ključne besede: Vatroslav Lisinski / Ignaz Fuchs, Ljubav i zloba, Porin, nacionalna opera, ilirizem.

\begin{abstract}
The article deals with the situation in the 1840s, when the young composer Vatroslav Lisinski (1819-1854) was asked by Zagreb patriots to compose a national opera. He was not musically well-educated for such a task, and the poets were not experienced in writing librettos either. The author presents these issues, the ensemble, and the performance of Ljubav $\mathrm{i}$ zloba (Love and Malice) by way of an imagined monologue by the composer.
\end{abstract}

Keywords: Vatroslav Lisinski / Ignaz Fuchs, Love and malice, Porin, national opera, Illyrian movement.

When a historian looks back on a particular past event, he is more or less able to construct a series of events according to the facts known. This type of bird's-eye view perspective enables him to observe it in its totality and to perceive the results of certain actions by the persons involved in it. However, very often he can only assume, or even only imagine, the possible impetus or direct cause of certain actions. Yet it is possible to imagine how a person would feel and react to finding oneself in the very same situation, and to hypothesize what knowledge and facts the person was aware of. I felt the impact of such questions and issues when dealing with this topic. Therefore, I have decided to try to slip into Lisinski's shoes and tell the story through a sort of "imaginary memoir" from his perspective, with some additional commentary for the reader.

$* * *$

One of my crucial memories from my student days dates back to the summer of 1841: on a small stage in the backyard of my family home, ${ }^{1}$ the Domorodno kazališno društvo (Patriotic Theatre Company) performed a historical play, Juran and Sophia, or the Turks

1 The house where Vatroslav Lisinski (1819-1854) was born is in Zagreb, Ilica 206 (today no. 37). 
at Sisak, ${ }^{2}$ by the 26-year-old historian and writer Ivan Kukuljević Sakcinski, who was only three years older than I was. ${ }^{3}$ The play had already been performed two years earlier at the fortress of Sisak, ${ }^{4}$ but for the performance at our new beautiful theatre in Zagreb ${ }^{5}$ new music had to be composed, as patriotic as the play itself. Therefore, Ferdinand Wiesner, who was already known under his Croaticized name Ferdo Livadić, ${ }^{6}$ composed some songs. The instrumentation was completed by an orchestra member, Wilhelm Weisz. ${ }^{7}$

For me, a young law student and almost an amateur musician, ${ }^{8}$ the artistic director of the patriotic students' singing society, already known among my friends under a Croaticized version of my name as Vatroslav Lisinski (although I was baptized as Ignatius Fuchs, and only later carried out the official change), ${ }^{9}$ that performance meant a feast of patriotic emotions. Therefore, I decided to use my whole energy and musical creativity in the service of the Illyrian movement, which I had already joined during my secondary-school years in the mid-'30s. I was aware that my musical education had lacked consistency; I had started to learn music very late. In my early teens my parents came to the idea that training for a teacher's profession (which included the tasks of an organist) might be suitable for my weak health, so they arranged private teachers in piano and basic music theory for me, not knowing that this would result in my choosing music as a profession. Unfortunately, the music school of the Zagreb Music Society (usually called

Lovro Županović carried out a thorough study on Vatroslav Lisinski and presented information on many sources and documents. See Županović, Vatroslav Lisinski (1819-1854).

2 Juran i Sofija, ili Turci kod Siska. The play was performed for the first time in Sisak in 1839, then the next year in the Zagreb theatre, and also in 1841 on the open-air stage.

3 Ivan Kukuljević Sakcinski (1816-1889).

${ }^{4}$ On that occasion only some already existing epic songs were performed. Županović, "Važnost Ljudevita Gaja za hrvatsku glazbu preporodnog razdoblja", 171-172, after the writings of Franjo Ksaver Kuhač, or: Katalinić, "Paralelni svjetovi ili dvostruki identitet?" 336, according to the journal Danica.

5 The first purpose-built theatre in Zagreb was opened in 1834, on a municipal lot, financed by the merchant Kristofor Stanković. It was quite badly damaged in the 1880 earthquake. However, it was later repaired to some extent and used until 1895, when the new theatre building by Fellner and Helmer was opened. Today the old theatre is a municipal building, having no trace of its former function. The festive curtain, preserved in the City Museum in Zagreb, portrays some national symbols characteristic of the still-young national movement: a grandfather playing the national epic instrument the gusle, telling/singing (obviously national) poems to his grandson, and a fairy under the coat of arms of the Triune Kingdom of Croatia, Slavonia and Dalmatia. On the topic of national symbols in the theatre see: Katalinić, "The visualisation of the national in nineteenth-century opera in Zagreb", 45-65.

6 Dimitrija Demeter called him Livadić in his review of a patriotic soirée at the house of Count Janko Drašković on 5 April 1839. See Majer-Bobetko, "Ferdo Livadić u tisku svoga doba", 31. Livadić (1799-1879) was a popular composer of heroic songs, lyrical songs and piano pieces.

7 Some songs are still kept at the Croatian Music Institute in Zagreb.

8 After gaining some basic piano skills from his sister Maria, Lisinski took private lessons in music theory: possibly with Johann Reyschil, and undoubtedly with Joseph Sojka and Georg Carl Wisner-Morgenstern.

9 On the change of Lisinski's name, see Franković, "Molba Vatroslava Fuchsa za promjenu prezimena u Lisinski”, 297-299. 
the Musikverein), founded in 1829, at that time offered lessons only in strings, winds and singing, so my entire music education was gained outside any institution. Nevertheless, my conducting and occasional arrangements of folk and traditional tunes for the singing society founded by my classmate Alberto Štriga (1821-1897), a singer and jurist, gave me the impetus to try my skills in composition as well. My own first "real" output - a choir piece on lyrics by the Croatian writer Pavao Štoos ("Iz Zagorja od prastara") - was publicly performed for the first time in the summer of 1841, for a birthday party prepared for Ljudevit Gaj, one of the "fathers" of the Illyrian movement, held on the very day of my own twenty-third birthday. This rousing song immediately became very popular, even more after some musical and textual revisions were made. The enthusiasm expressed both by my friends and the audience stimulated my desire to make further musical contributions to the national movement. I was encouraged to continue with composing dances for popular Illyrian balls and feasts, as well as solo songs and heroic choral songs. These were the results of my hard work in music theory with the best-educated musician in Zagreb - Georg Carl Wisner von Morgenstern. ${ }^{10}$ My family home became a centre for patriotic gatherings and discussions. The fundamental guide for my musical ideas was the proclamation on national art by Ljudevit Gaj, in which he wrote that national music "should be drawn from the people, and when it creates something new let it also be in the spirit of the people - but not as unadorned and naïve as the products of the simple people but rather sophisticated, refined, according to the principles of art and aesthetics: thus we shall achieve what other nations lack: true national music". ${ }^{11}$ Therefore, I practised the combination of simple compositional skills and national ideas by introducing and arranging various Slavic pieces (e.g., Slovene, Russian and Polish) for my singing society's repertoire. Of course, I also enjoyed some of the opera performances given in the Zagreb theatre, although the quality and success of the itinerant theatre companies (usually from Austria, performing the international operatic repertoire) did not always display the expected level of quality. One can easily remember Carl Mayer's company in 1838 and, even more, the following one of Heinrich and Carl Börnstein from Linz, who not only performed operatic pieces by Bellini, Donizetti, Auber and even Mozart quite well, but also invited some respectable guest singers. On the other hand, the national theatrical repertoire was only to be established in the times to come: other than Kukuljević's play with incidental music, there existed mostly translated German comedies and plays with local and national music, sometimes even performed in national costume. The audiences were eager for national art and they often accepted such light pieces with enthusiasm only because they were performed in the national language. Although my financial situation - especially after 1842 , when I started to volunteer as a municipal clerk - did not allow me to attend these theatre events regularly, I stayed in contact with musical performances

${ }^{10}$ Georg Carl Wisner-Morgenstern (1783-1855), a native of Arad, first arrived as the secretary to Count Ladislaus Erdödy to his manor in Veliki Marof near Varaždin, and after two years moved to Zagreb. Although a jurist for his primary profession, he turned out to be a well-educated musician, and music became his definitive source of income.

${ }^{11}$ Cited after Kuhač, Glasbeno nastojanje Gajevih Ilira. Povjestna crtica, 19-21 and in: Andreis, Music in Croatia, 124. 
mostly by attending concerts at the Musikverein and various other singing societies, which were even more nationally coloured.

In 1844 , by which time I had composed only a scant two dozen musical pieces, mostly songs and piano compositions in which I tried to imitate the sound and simple structure of the local folk music, my ambitious friend Alberto Striga came up with a new idea and formulated it almost as a command: You have to compose an opera! This was only the final and most definitive expression of this idea, which had been on his mind ever since our newspaper had published a brief report on the performance of the opera A Life for the Duke [sic] by Mikhail Glinka in St Petersburg, ${ }^{12}$ and after an extensive article on Russian music was published in Danica ilirska. ${ }^{13}$ Still, was I - a young and inexperienced musician - being invited to offer an answer to such a demanding task? Some critics were already pointing to Ferdinand Wiesner (a.k.a. Livadić), as, for example, in the review of one of the nationally-coloured entertainments at the palace of Count Janko Drašković, which stated:

It is a pity that Mr. Livadić, who - as an Illyrian - could be with some more care what Glinka is for the Russians and Tomašek for the Czechs, because he is full of musical imagination and knowledge. Therefore, it is a pity that his national compositions have not been published, for they are delicate - as it seems to us - in their sensibility awakened by the beautiful nature surrounding the town of Samobor. By his published output, he would have given the most beautiful present not only to us Illyrians, but also to all Slavic brothers and all music lovers. ${ }^{14}$

However, the national idiom in the theatre did not make any significant progress. I remember the enthusiastic call of the theatre director Heinrich Börnstein already in 1839 in our journal Danica, ${ }^{15}$ trying to raise the national self-awareness and to stimulate the foundation of the national theatre. Despite being a German, he was entirely aware of its importance! We all agreed with his words that the theatre is the right place to bring the national idiom to life, as the Hungarians did in Budapest, and our Czech brothers in Prague. However, I felt too weak to carry out a part of the task. My repeated resistance, supported by the fact that there were no similar national works in Croatia, no adequate libretti in Croatian and that I had never composed such a demanding instrumental work, was not taken seriously. Striga himself constructed the fundamental plot, and found an amateur poet, Janko Car, who was willing to write a libretto. He forced me to put aside all my other musical duties and stick to the composition of the opera, named Ljubav i zloba (Love and Malice). I thought to write a few arias, some ensembles and choruses, with simple harmonisations, all bound together with a series of spoken dialogues, and accompanied by the piano or a chamber ensemble. Such a Singspiel might then be performed

12 The title is cited after Ilirske narodne novine III/4, 14 January 1837, 3-4, meaning the opera $A$ Life for the Tsar. The short article describes the reopening of the theatre after its renovation.

${ }^{13}$ Danica ilirska VII/47, 20 November 1841, 194-195.

${ }^{14}$ Danica ilirska V/16, 20 April 1839, 64.

${ }^{15}$ His proclamation "O utemeljenju ilirskog narodnog kazališta" was published in Danica ilirska V/46, 1 December 1839. 
by a circle of national enthusiasts. ${ }^{16}$ Nevertheless, Štriga's ideas were much more ambitious because he realized the importance of such a work for the national movement: a representative form as an opera in the national language would be a confirmation of national strivings and would fill the lack of national repertoire on the musical stage. On the other hand, Štriga insisted on immediate performance of the first arias as soon as I had finished them in order to check the reaction of the audience and to prepare them for the entire work. The reviews were enthusiastic and stimulating, especially the one in the German cultural newspaper Luna:

In the entr'acte Mr. Frasinelli sang with tumultuous applause an artistic and very demanding aria also in the national language by Mr. V. L., a gifted young man, whose promising musical talent is proved by many of his musical attempts - among them many favourite folk melodies - and from whom a performance of a valuable larger composition is soon to be expected. Mr. Frasinelli performed in an imposing Dalmatian-Croatian costume and was called out repeatedly, as well as the composer. ${ }^{17}$

Our Croatian newspapers were also full of enthusiasm; ${ }^{18}$ even the German Agramer politische Zeitung brought some flattering words: "Mr. Frasinelli sang a demanding virtuoso aria with the text in the national language, composed by Mr. Fuchs, as a specimen from an opera, which would be - as said - executed by an amateur company as a benefit performance." 19 A few months later, Štriga himself performed an aria, but the most successful was, of course, Countess Sidonija Rubido Erdödy, who sung an aria of the main female role, named Ljubica, and gained ovations with her crystal-clear voice. She was always an ardent and important promotor of our national ideas. With another aristocrat, Count Janko Drašković, she was very helpful in organising patriotic feasts and balls.

However, as I proceeded with this demanding task, I realized the many weak points of the libretto: it was clumsy and not dramatic at all. Štriga gave his hand here too. He found a professional librettist, Dimitrija Demeter, a famous playwright and director of the national theatre company, who rewrote the entire first act, and finished the second one; he placed the plot - an eternal love triangle and rivalry of two youngsters for a beautiful and demure girl - into the historical frames of sixteenth-century Dalmatia. For the musical part, I got my satisfaction in the newspaper reviews, when the critics realized that the spirit of the national popular music gave the decisive tone to my creation. It was the most difficult task, because I had nothing to lean on, and here my experience in arranging popular tunes for my singing society was most useful. I tried to create simple melodies imitating the folk tunes and lyric atmosphere in the love scenes; on the other hand, the heroic tunes of our epic songs gave the tone to the scenes of action and combat. My problem - the lack of practical knowledge in orchestration - seemed immense to me. Therefore, Štriga persuaded the musician and teacher Wisner-Morgenstern to complete the instrumentation

${ }^{16}$ That idea was pointed out by F. Ks. Kuhač in Vatroslav Lisinski i njegovo doba, 36.

${ }^{17}$ Luna XIX/21, 16 March 1844.

${ }^{18}$ Danica horvatska, slavonska i dalmatinska X/11, 16 March 1844, 4.

${ }_{19}$ Agramer politische Zeitung XIX/20, 9 March 1844, 6. 
for a reasonable price and thus fulfil his patriotic duty. ${ }^{20} \mathrm{I}$ could tell that his work was valuable, but in my opinion it was too "classical", traditional and complicated, sometimes opposing the simple and clear melodic shapes of my melodies, but my knowledge of compositional handicraft was too weak for me to be able to give sufficient impulse in the right direction. In spite of all this, I was more than pleased with his help, and started immediately to rehearse with the singers. Some political events directly influenced the advancement of our work. In July 1845, there was a protest against Ban Franz Haller and the fraudulent local elections, and almost 50 patriotic students were shot in front of the government building. ${ }^{21}$ Our very young tenor singer, Franjo Stazić, ${ }^{22}$ was also among the wounded, so that we had to wait for his recovery to proceed with our rehearsals.

The eminent patriots worked hard on the task of establishing a national theatre. One of the outcomes that Börnstein urged with his proclamation in 1839 was the Parliament's decision to found the national theatre board, named by our bishop Juraj Haulik. ${ }^{23}$ The historian Kukuljević had also recently pointed out in his proclamation the importance of the national theatre in the education of the nation, in addition to the university and a learned society with the museum. ${ }^{24}$ However, the German and Italian opera companies still governed our musical stage, because there were not enough educated local musicians to take this task over for a longer period. Therefore, we gathered a rather odd ensemble for the performance. As Zagreb did not have its own professional opera company who could perform well in the Croatian language, there were my amateur friends (though very professional in their attitude to do their best). Franjo Stazić, who was working hard to become a good professional tenor (and whose later career proved his abilities), got the role of Vukosav. There was also my friend Alberto Štriga as Obren, actually a lawyer with a beautiful baritone. In the opera plot, both of them were in love with Ljubica, sung by our eminent soprano and patron of the national movement, Sidonija Rubido (born

${ }^{20}$ His involvement in orchestrating the opera was mentioned in the press, as well as in all Lisinski's biographies (Kuhač, Vatroslav Lisinski, 47; Kassowitz-Cvijić, Vatroslav Lisinski u kolu Ilira). According to the critic in Danica, Lisinski made the piano version, and Wisner-Morgenster did the entire orchestration ("Pàrva izvorna ilirska opera 'Ljubav i zloba' od Vatroslava Lisinkoga," Danica horvatska, slavonska i dalmatinska XII/14, 4 April 1846, 3).

${ }^{21}$ A monument to the 1845 "July victims" was erected in 1855 . The thirteen deceased victims were buried at the Jurjevsko graveyard, later transferred to the Mirogoj graveyard together with the monument.

${ }^{22}$ It was said that Stazić - whose real name was Franz Steger (1824-1911) and came from Buda via Novi Sad to Zagreb - had his début in Lisinski's first opera. However, he took part not only in 1846 (as in: Barbieri, Hrvatski operni pjevači, 12), but already during 1845 in Mazza's opera company in Donizetti's Lucia di Lammermoor; he also participated as a soloist in patriotic festivities and benefit parties (cf. Danica horvatska, slavonska i dalmatinska XI/11, 15 March 1845). He became a celebrated singer of the Vienna Opera, and sang in Prague and Budapest too.

${ }^{23}$ By the proclamation of the Parliament, according to article XXVII, Bishop Haulik named nine members with Count J. Drašković as its president (cf. Ilirske narodne novine VI/72, 8 September 1840, 1). On that topic, see more in: Katalinić, "Paralelni svjetovi", 337.

${ }^{24}$ Ivan Kukuljević-Sakcinski, "Einige Bedürfnisse Kroatiens und Slawoniens”, Agramer politische Zeitung XX/76, 20 September 1845, 336-338. 
Countess Erdödy). ${ }^{25}$ The pharmacist Kamilo Wiesner (a.k.a. Livadić), the son of our renowned composer, sang with his beautiful basso the role of her father, Count Velimir, a young nobleman was played by Ljudevit Pihler (tenor) and Vukosav's servant Branko was played by Franjo Wisner-Morgenstern (bass-baritone), the son of the composer Georg, who arranged the instrumentation. The theatre orchestra took part in the performance, reinforced by some Musikverein professors, and with some military as well as amateur musicians; their conductor Eduard Angel from Mazza's Italian opera company, as well as the stage designer Steiner and director Eduard Hörenstein were rare professional members of our ad hoc and mostly amateur crew. After various problems had been resolved, the opera was able to be staged. The plot, published in the newspaper before the premiere, was very simple: two young men (Obren and Vukosav) are in love with Ljubica (the daughter of the Dalmatian count Velimir), but she prefers Vukosav. Obren, jealous and mean, captures them in order to prevent their reunion, but Vukosav's servant releases them. The fact that my music was characterized as national, in combination with the sweetness of our national language, could have resulted in the success not only of my work but also in our national strivings in general. The opera was heralded as an original national piece in all the journals and newspapers, ${ }^{26}$ the plot was presented there, too, and the libretto was printed and sold in bookshops. Special attention was given to the fact that "in many choruses the best-known forces of domestic patriotic ladies and gentlemen will be united", and "the first musical eminencies of Zagreb and Karlovac will take part in the orchestra". ${ }^{27}$ Finally, the 28th of March 1846 arrived, and I was so nervous that I could hardly breathe when the curtain was rising.

I could never have imagined how successful the first performance of the opera Love and Malice ${ }^{28}$ would be. The theatre was sold out for all five following performances, including the one for the birthday of King Ferdinand II, as well as the sixth one the next year, on the day the Croatian parliament proclaimed Croatian the official language, thus

${ }^{25}$ Sidonija Erdödy (1819-1884) took part in the national revival movement, singing patriotic songs in the Croatian language since she was 14. She took music lessons in Zagreb with the Czech alto Nanette Karlitzky and the Berlin Opera star Johanna Ennes.

${ }^{26}$ In addition to local Croatian and German newspapers, the announcements and/or reports on the "original national opera" were published not only in Vienna, but also in Milan (Gazetta musicale di Milano V/18, 3 March 1846, 143: Notizie: Agram (Croazia)) and Paris (Revue et Gazette musicale de Paris XIII/16, 19 April 1846, 127: Nouvelles. Chronique étrangère. Agram (Croatie)), along with short notifications about its performances. For example, the Viennese Der Humorist (9 April 1846, 4 (348), edited by the famous satirical writer and journalist Moritz Gottlieb Saphir, published a few lines on "Die erste kroatische Originaloper 'Ljubav i zloba', Text von Dr. Demeter, Musik von dem jungen Komponisten Vatroslaw Lisinski, instrumentirt von Franz [sic] Wisner von Morgenstern, ist kürzlich vier Mal mit steigendem Beifall von Dilettanten in Agram aufgeführt worden."; Il Pirata (5 May 1846, 6) wrote (with many errors): "Anche un'Opera croata! Quanto prima si udrà in Agram un'Opera scritta in lingua croata, intitolata Ljutavi [sic] Zloba, parole del signor Demetes [sic], musica di Varoslav [sic] Linsinski [sic]."

${ }^{27}$ Luna XXI/22, 17 March 1846.

${ }^{28}$ Ljubav i zloba, translated into German as Liebe und Bosheit, or Liebe und Kaballe. 
replacing Latin..$^{29}$ One newspaper critic enthusiastically considered the opera to be rightly called an Illyrian one, "because in it musical characters of all Illyrian provinces have been united", ${ }^{30}$ which was certainly my intention. The beautiful review in two issues of Danica, signed by an anonymous reviewer, was poetic, professional and literarily worthy. ${ }^{31}$ The singers were always called back to the stage repeatedly, especially Countess Rubido. On the wings of this success, Štriga supported me in my wishes to devote more energy to music than to law, and started at once to arrange additional musical training for me. In Zagreb, I would have been able to receive only the basic education at the Music Society School, so to go to Prague seemed to be an optimal choice for a Slavic patriot with my compositional sensibility. Stanko Vraz made some efforts to promote my opera in Slavic countries and to get it published, but the lack of patrons of Slavic music eventually made this impossible..$^{32}$ My finances were more than dire; therefore, Štriga arranged various concerts and guest performances in order to get financial support from patriotic noblemen and citizens. During our concert tour in Serbia in 1847, my first composition was published in Graz: a solo song on a Slovakian text, which brought my name into the newspapers again.

The political atmosphere in Zagreb and Croatia during the late 1840s became more and more vibrant, but I experienced the revolutionary year 1848 in Prague. I was too old for the Conservatory - I was already 28 when I arrived there - and I decided to look for private studies in composition and orchestration; after examining my compositions, Jan Bedřich Kittl, the director of the Conservatory himself, offered help in this matter. I was grateful to my teacher for his systematic efforts, and did my best to satisfy him, but I also did not want to neglect my own musical impulses. Orchestral and choral works, solo songs and some arrangements were my initial results. But the dream of a national opera was awakened again from my homeland: the good old man Demeter, who had re-created the libretto of my theatrical first-born, found a new topic, which seemed to be suitable for a real national opera: a theme placed in early Croatian national history, when Duke Porin fought against the Frankish invaders (in the ninth century). In Prague I was able to enjoy very good theatre and operatic performances and - combined with my musical progress - I considered myself ready for this challenge. However, Dr. Demeter was very slow, so I had to urge him onward, especially because the patriotic atmosphere could be felt in Prague so intensely that I was able to draw parallels with the heroic news received from my sister and friends back home. Moreover, the Czech people had done a lot of work on collecting their national treasures; I have to point out above all Karel Jaromir Erben, for whom I brought recommendations from our patriot Stanko Vraz, and who

${ }^{29}$ That happened on 23 October 1847, when Ivan Kukuljević-Sakcinski demanded that Croatian should be the official language of the Croatian parliament.

30 "Pàrva izvorna ilirska opera 'Ljubav i zloba' od Vatroslava Lisinkoga", Danica horvatska, slavonska i dalmatinska XII/15, 11 April 1846, 3 (59).

${ }^{31}$ It is said that the patriotic poet Stanko Vraz stood behind the text, as he probably wrote the sonnet to Sidonija Rubido published on the title page of Danica horvatska, slavonska i dalmatinska XII/14, 4 April 1846.

32 Županović (Vatroslav Lisinski, 48) cites the correspondence between Stanko Vraz and František Palacký. 
had already published two collections of folk songs. In that sense, I tried to recollect all the folk songs that I had notated and arranged, to analyse them and to reconstruct their formal and structural compositional characteristics. How important it would be to have such a collection of Croatian folk songs, which could serve as a source and a basis for the creation of national art music! My few transcriptions, gathered from my friends in and around Zagreb, were nothing but a weak start that I wanted to continue and expand.

The liberal ideas in Prague did not pass me by, so I was able to share my feelings with those who stuck to Austro-Slavic ideas. I attended the Slavic Congress, but I did not have much time, and, even more, I did not have enough money to waste my time with never-ending political discussions. To the contrary, these events encouraged me to stick to my work, to be as patriotic as possible by means of my music. The glorious news from Croatia, ${ }^{33}$ like the election of Ban Josip Jelačić, was spiritual nourishment for me, who was hungry almost every day, and my composing was progressing with satisfaction, although I did interrupt it twice for long visits to my beloved hometown. Even in hard times, when I received the report of my dear sister's passing away, music was my sanctuary, especially vocal pieces and piano miniatures. I tried to develop a feeling for the Czech language and set it to music too, but my main task became composing the new opera. After a year, I had already finished the overture and three acts. Demeter imagined it as a grand romantic opera in five acts, but he was always late with sending me fragment by fragment, so that I was not able to receive the entire work almost until the end. My last few months in Prague were not as happy as the earlier ones, although my pieces were performed in concerts and received with warm enthusiasm. My further publications in Prague were mentioned in the newspaper more often. ${ }^{34}$ The depressing news on the absolutist rule established at home, my illness and my poverty forced me to return home to rest and recover, but the hard times continued there, too. I finished my second opera Porin, and every now and then I was able to have my orchestral work, and an aria or two, performed publicly with good reviews by the critics. I also organized and conducted the Musikverein ensemble in a series of concerts where mostly my music was played but, as my engagement was treated as a honorary one, my finances remained generally worse than poor. I also tried to organize a performance of my new opera in its entirety, but the

${ }^{33}$ On the situation in Croatia in 1848-49 see: Katalinić, "Die Musikkultur in Zagreb im Jahr 1848/49", 209-219.

${ }^{34}$ For example, the Wiener Zeitung (nr. 206, 29 August 1850, 16) published following news: "Vatroslaw Lisinsky's neulich angekündigte Kompositionen cechischer [sic] Lieder mit beigefügter kroatischer Uebersetzung haben bereits die Presse verlassen und geben ein neues Zeugniß von der Befähigung dieses jungen südslawischen Komponisten; Lisinsky's Lieder sind dem bekannten Ambros von Vranicany dedicirt." It is a collection of six solo songs on texts by Czech poets (with Croatian translation) entitled Šestero českých pisní, published in Prague in 1850. The collection was dedicated to Count Vranicany, probably because he was the first on the list of financial supporters of Lisinski's studies in Prague (cf. Županović, Vatroslav Lisinski, 55-56, fn 177). Others were Ban Jelačić and a series of noblemen (Janko Drašković, Ladislav Pejačević, Franjo Kulmer etc.) and renowned citizens (Ljudevit Gaj, Franjo Stauduar, Josip Juratović etc.). However, that support radically diminished in 1849 and 1850 because of general poverty and some other, mostly political, reasons. 
Patriotic Theatre Society was abolished, the professional singers went abroad, and the performing demands in my score were too difficult for the local soloists and ensemble. The orchestra was quite modest, too, predominantly consisting of military musicians, professors of the Musikverein and some amateurs. Concerning the opera, my idea was to confront two military and national entities in music - the Croats and the Franks - thus identifying the first with simple, folk-like melodies in arias and choruses, and the second with virtuoso arias in the style of Bellini; the sample pieces that were publicly performed met with enthusiasm for my musical skill. I was especially proud of a chorus of Croatian women, where I tried - in Gaj's sense - to use the quality of the modal character of the folk tradition, built upon the foundation of classical harmony.

Now that I am lying ill and weak in my bed, becoming completely dependent on the help of my friends, I think of my decision to follow the path of music instead of sticking to my juridical career. I do not regret anything although I remained poor, but I hope to have satisfied my friends and my compatriots, figuring as the musical voice of my nation.

\section{The epilogue}

Vatroslav Lisinski died in 1854, at the age of 35. He left an opus of some 170 works: in addition to his two operas mentioned above, it consists of some 70 solo songs on German, Croatian, Czech and Slovak texts, some 40 choral pieces, notated and harmonized folk songs, some 30 piano works, 15 chamber pieces and 15 orchestral pieces - mostly overtures.

His first opera, Love and Malice, was heralded and received as the first Croatian national opera. In fact, it was a type of rescue opera, not fulfilling the complete aim of a national piece primarily because of the lack of a national topic. ${ }^{35}$ However, its music was recognized as national because its style was close to the national music and folk tradition - not the rural, but the urban one, mostly in the heroic spirit of rousing songs, up-to-date and known to the audience at that time. It seems that this melodic simplicity, almost naiveté, and the transparent instrumentation, along with naive verses in the national language, were decisive in defining this opera as a national one. The parallel can be drawn to Lisinski's instrumental compositions, as judged by the critic Ljudevit Vukotinović in 1843: "His tunes are good; and it is right that Mr. Lisinski sticks to his own original magic simplicity and that he is not yielding to Italian colour painting or difficult German music, which is not at all suited to our folk songs." ${ }^{36}$ The fact is that at the early stage of the national revival the national identity had to be confirmed through national culture, as well as by means of an opera. Therefore, all energy was focused in its creation and realization, which was acclaimed by the audience.

${ }^{35}$ Demeter did somehow place the plot in the historic frame of sixteenth-century Dalmatia, thus pointing to one of the important myths of the nation - its territory - i.e., Dalmatia being the part of the "once glorious" Triune Kingdom, although in the nineteenth century it was actually under direct Viennese rule.

${ }^{36}$ Ljudevit Vukotinović, Lětošnje poklade u Zagrebu, Danica hrvatska, slavonska i dalmatinska IX/10, 11 March 1843, 3 (39). 
However, Lisinski's music was not always judged so favourably: Kuhač names Leopold Alexander Zellner, a pianist and journalist originating from Zagreb, editor of the Viennese Blätter für Musik, Theater und Kunst, as a "great admirer of Lisinski". ${ }^{37}$ However, in 1864, he published a series of articles presenting the music situation in Zagreb during 1840 s and 1850 s by a certain A.D.K., ${ }^{38}$ who wrote:

"Eines der gewichtigsten dieser Hindernisse war der mittlerweile eingetretene sociale Umschwung, der im Nationalitätsprincipe seinen potenzirten Ausdruck fand. Man wollte ein Kunstleben, aber bloß ein nationales, ohne zu erkennen, daß ein specifisch nationales Kunstleben eine große ausgebildete Kunstvergangenheit zur unbedingten Voraussetzung haben muß .... Da tauchte plötzlich eine Persönlichkeit auf, in welcher die nationale Partei den gesuchten Kunstmessias zu erblicken glaubte. Der Mann, ein schwacher Musikdilettant, seines Stammes ein Deutscher, der auf den Namen Fuchs hörte, wußte sich die Situation zu Nutzen zu machen. Er verwandelte sich in Lisinsky, schrieb ein paar unbedeutende croatische Lieder, und ward somit der Abgott und Vertreter der nationalen Kunst. Man brachte Mittel auf, dieses nationale Genie ausbilden zu lassen, sandte ihn auf's Prager Conservatorium, wo er sich in der Composition die letzten Grade erwerben sollte. Nach etwa Jahresfrist kehrte Lisinsky zurück und brachte die Partitur einer croatischen Oper mit, die indessen bis zur Stunde ihrer Auffürung harrt, denn womit hätte man sie aufführen sollen?"39

However, this series of half-truths did not represent the opinion of the majority, and the performance practice during more recent history has testified to the gifted musical output of the composer and made his works regular parts of the national repertoire.

After his improvements in the study of composition and related disciplines, Lisinski's approach to the idea of national in music advanced too, above all based on the folk songs that he tried to collect and analyse in order to apply their compositional characteristics in his compositions. Regrettably, the first collection of Croatian folk tunes ${ }^{40}-$ compiled $^{2}$ by Councillor Karlo Catinelli (1807-1864) was published in Vienna, presumably, in 1849, but it seems that Lisinski did not take advantage of it because he probably did not know about it, having spent so much time in Prague.

He did not live to see his second opera Porin staged - this only happened almost 50 years after its creation, on 2 October 1897. At that time, when operas by Wagner, Massenet and Bizet dominated the Zagreb musical stage, Lisinski's second opera, actually a grand early romantic piece, was accepted with respect due to its national importance, but described as antique and old-fashioned.

Due to this delay in the first performance of Porin, a large lacuna occurred in the

${ }^{37}$ Kuhač, Vatroslav Lisinski, 116.

${ }^{38}$ According to the bitterness of the text, one might presume that the author was Alexander Kovácsics, a pro-Hungarian-oriented composer, conductor and pianist in Zagreb, an opponent to the Illyrian movement and secretary to the Hungarian Casino in Zagreb. In 1848 he emigrated to Paris, returning to Zagreb in 1856, where he died in the 1860s, impoverished and forgotten. (cf. Ajanović, "Kovačić, Aleksandar", 785).

39 "Aus Agram", Blätter für Musik, Theater und Kunst, 24 July 1864, 1.

${ }^{40}$ Južno slavljanske pučke pěsme. Svezak I. Pěsme iz Slavonie (South Slavic Folk Songs. Vol. I. Songs from Slavonia), containing some 25 tunes from the region of Požega, Slavonia. 
national operatic repertoire. Namely, from the performance of Love and Malice in 1846, and the foundation of the Zagreb national opera theatre in 1870, when the national-historical productions by Ivan Zajc started to be staged, not a single national opera was performed, and, beside Porin, not even composed, due to political, cultural and personal reasons.

Moreover, a sort of paradox occurred: Lisinski was always complaining about the lack of collections of Croatian folk songs. Apart from the small collection by Catinelli, the most extensive one was arranged and edited by Franjo Kuhač only later, in 1878-81, offering composers a foundation on which they could build "national works". Still, in a review of Zajc's opera Pan Twardowski in 1880 Kuhač himself complained: "We think that the duty of our poets was to leave the field of cosmopolitism and to devote themselves to domestic themes," and further on concerning music: "If we charged the libretto not to grow out of Croatian history or everyday life, the same is to be said for the music [...] Since our folk-songs were published, the musicians of other nations have thrown themselves onto them like bees onto honey. And Herr Zajc, who sits here at their sources, has he made no profit out of this richness?" It shows how the situation radically changed when comparing the first and the second halves of the nineteenth century: the national issue no longer had to be proved at any price - the question of finding a national identity was no longer dominant in Croatian society, culture and music at large.

\section{Bibliography}

Agramer politische Zeitung, 20 September 1845.

Agramer politische Zeitung, 9 March 1844.

Ajanović, Ivona. “Kovačić, Aleksandar”. Hrvatski biografski leksikon, vol. 7, 785. Zagreb:

Leksikografski zavod Miroslav Krleža, 2009.

Andreis, Josip. Music in Croatia, translation by Vladimir Ivir. Zagreb: Institute of Musicology - Academy of Music, 1982.

Barbieri, Marija. Hrvatski operni pjevači. Zagreb: Nakladni zavod Matice hrvatske, 1996. Blätter für Musik, Theater und Kunst, 24 July 1864. "Aus Agram”.

Börnstein, Heinrich. "O utemeljenju ilirskog narodnog kazališta”. Danica ilirska, 1 December 1839.

Catinelli, Karlo Maksimiljan. Južno slavljanske pučke pěsme. Svezak I. Pěsme iz Slavonie. Wien [1849?].

Danica horvatska, slavonska i dalmatinska, 15 March 1845.

Danica horvatska, slavonska i dalmatinska, 16 March 1844.

Danica horvatska, slavonska i dalmatinska, 4 April 1846.

Danica horvatska, slavonska i dalmatinska. "Pàrva izvorna ilirska opera 'Ljubav i zloba' od Vatroslava Lisinkoga". 11 April 1846.

Danica horvatska, slavonska i dalmatinska. "Pàrva izvorna ilirska opera 'Ljubav i zloba'od Vatroslava Lisinkoga”. 4 April 1846.

Danica hrvatska, slavonska i dalmatinska, 11 March 1843.

Danica ilirska, 20 April 1839. 
Danica ilirska, 20 November 1841.

Der Humorist. "Die erste kroatische Originaloper 'Ljubav i zloba". 9 April 1846.

Franković, Dubravka. “Molba Vatroslava Fuchsa za promjenu prezimena u Lisinski”. Arti musices 21, no. 2 (1990): 297-299.

Gazetta musicale di Milano. "Notizie: Agram (Croazia)". 3 March 1846.

Il Pirata, 5 May 1846.

Ilirske narodne novine, 14 January 1837.

Ilirske narodne novine, 8 September 1840.

Kassowitz-Cvijić, Antonija. Vatroslav Lisinski u kolu Ilira. Zagreb: Matica hrvatska, 1919. Katalinić, Vjera. “Die Musikkultur in Zagreb im Jahr 1848/49”. In Musik und Revolution, edited by Barbara Boisits, 209-219. Wien: Hollitzer Wissenschaftsverlag, 2013.

"Paralelni svjetovi ili dvostruki identitet? Strane operne družine i nacionalna glazbena nastojanja u Zagrebu u prvoj polovici 19. stoljeća”. In Musicologie sans frontières. Essays in Honour of Stanislav Tuksar, edited by Ivano Cavallini and Harry White, 323-340. Zagreb: HMD, 2010.

"The visualisation of the national in nineteenth-century opera in Zagreb".

In Music, Politics and Ideology in the Visual Arts, edited by Paweł Gancarczyk and Dominika Grabiec, 45-65. Warsaw: Instytut Sztuki PAN - Liber Pro Arte, 2015.

Kuhač, Franjo Ksaver. Vatroslav Lisinski i njegovo doba, Zagreb: Matica hrvatska, 1904. Glasbeno nastojanje Gajevih Ilira. Povjestna crtica. Zagreb: Naklada knjižare Mučnjak-Senftlebenove, 1885.

Kukuljević-Sakcinski, Ivan. "Einige Bedürfnisse Kroatiens und Slawoniens". Agramer politische Zeitung, 20 September 1845.

Luna, 16 March 1844.

Luna, 17 March 1846.

Majer-Bobetko, Sanja. "Ferdo Livadić u tisku svoga doba". In Ferdo Wiesner Livadić. Life and Opus, edited by Vjera Katalinić, 29-36. Zagreb: HMD, 2003.

Revue et Gazette musicale de Paris. "Nouvelles. Chronique étrangère. Agram (Croatie)". 19 April 1846.

Wiener Zeitung, 29 August 1850.

Županović, Lovro. "Važnost Ljudevita Gaja za hrvatsku glazbu preporodnog razdoblja". In: Radovi Zavoda za hrvatsku povijest, 3, no.1 (1973): 171-172. Vatroslav Lisinski (1819-1854). Život-djelo-značenje. Zagreb: JAZU, 1969. 


\section{KAKO USTVARITI NACIONALNO OPERO? PRIMER LISINSKI. IZMIŠLJENE SPOMINSKE SKICE Z EPILOGOM}

\section{Povzetek}

Sredi štiridesetih let 19. stoletja je skupina hrvaških navdušencev pod vplivom novice o uspešni izvedbi Glinkine opera Žizn’ za carja (Življenje za carja) v Rusiji zaupala precej neizkušenemu, a nadarjenemu skladatelju Ignazu Fuchsu / Vatroslavu Lisinskemu nalogo, da napiše hrvaško nacionalno opero. V Zagrebu, kjer je narodnostno mešano hrvaško, nemško in madžarsko prebivalstvo večinoma poslušalo predstave gostujočih nemških in občasno italijanskih opernih družb, so narodni jezik začeli normirati šele nekaj let prej. Najprej se je narodna kultura pojavila v budnicah in na plesih, mladi skladatelj pa je imel skladateljske izkušnje le iz pisanja klavirskih in vokalnih miniatur. Komponirati opero je bila zanj več kot ambiciozna naloga. Izvor, vplivi, dejavniki in rezultati prizadevanj Lisinskega so predstavljeni, analizirani in vključeni v širši okvir hrvaškega narodnega gibanja in izraženi kot namišljen monolog skladatelja samega. 